\title{
Analysis of Sustainable Development Aspects of The Value-Added Mineral Policy for The Raw Materials Industry of Electric Vehicle Battery Using the Analytical Hierarchy Process (AHP) Method
}

\author{
M. Atthar Majid, Rinaldy Dalimi* \\ Energy System Engineering, Faculty of Engineering, Universitas Indonesia
}

*Corresponding author:

E-mail:

rndalimi@gmail.com

\begin{abstract}
Indonesia is currently heading for a low-carbon economy transition, one of which supports this policy. Through Presidential Decree No. 55 of 2019, the Government issued the Battery-Based Electric Motor Vehicle Program. In support of this program, the Government has a policy of Increasing mineral added value or downstream program implemented since 2009 so that the production of electric vehicle batteries can be produced domestically so that the industry has added value that will affect sustainable development in the sector. There are three criteria for problems affecting mineral downstream policies to inhibit sustainable development from the electric vehicle battery raw material industry: economic, social, and Environmental. In this study, the Analytical Hierarchy Process method determines the priority order of alternative solutions to solve complex multicriteria Problems into a hierarchy. From the results of the Analytical Hierarchy Process analysis, it was concluded that to overcome downstream problems, first is Improving the Governance of Mining and National Intermediate and Downstream Industries (51\%), second is Infrastructure Development and Technology Development (31\%), and third is Improving Information System Data Availability and Quality (18\%).
\end{abstract}

Keywords: Analytical hierarchy process, downstream mineral program, sustainable development

\section{Introduction}

Currently, Indonesia's national energy policy strategy is directed at realizing national energy security. Indonesia is struggling to let go of policies that were not pro-energy efficient in the previous era. Indonesia's energy transition policy is expected to be developed as clean energy and affordable for the community. In terms of preparing the energy position to support the development and national security, Indonesia's national energy policy strategy is currently directed at realizing national energy security. Strategic energy reserve (Dalimi, 2020) is an activity that can be carried out to continuously maintain the national energy supply sustainability in the long term by regulating the use of potential energy resources owned by looking at the value (price) of energy based on time. (Because energy prices will be expensive). There are two scenarios in the Energy Reserve Strategy concept: (1) whether to export energy resources owned or used for longterm domestic needs, (2) whether to use energy resources for domestic purposes or import energy resources from other countries for future generations. For this reason, energy security is essensial for a country as the availability of sustainable energy sources that are not interrupted at an affordable price.

In the context of the transition to a low-carbon economy, the Government through Presidential Regulation (Perpres) Number 55 of 2019 concerning the Battery-Based Electric Motor Vehicle Program, continues to strive to improve energy conservation programs, with this 
policy in the future, the use of battery-based electric motorized vehicles can be massive. Implementation of which this program is also contained in the Grand National Energy Strategy Draft. Building a domestic battery raw material industry is one of the steps that can be taken to produce cheaper electric motor vehicles, and Indonesia is not dependent on other countries. The minerals needed for the battery industry are Lithium, Nickel, Manganese, and Cobalt. There are two types of electric batteries widely used today: Lithium-ion (Li-ion) and Nickel Metal Hydride (NiMH). Li-ion batteries use lithium and cobalt as electrodes, while NiMH uses nickel. The primary capital of raw materials for making electric vehicle batteries owned by Indonesia, such as Nickel and Cobalt, which are available in several areas including Sulawesi, Kalimantan, and Papua, Indonesia, could create a domestic battery raw material industry. In addition, a national electric vehicle battery industry can create sustainable development by increasing state revenues from this industry to be used inequitable development, especially for other regions that do not have mineral wealth and can pave the way for economic activity or even industry. Others, because this industry cannot stand alone if other industries or services do not support it.

There are still problems in the sustainable development of the policy to increase the added value of minerals. The unintegrated resolution of these problems from upstream to downstream for the program to increase the added value of minerals can cause the acceleration program for battery-based electric motor vehicles to be hampered in providing raw materials. for the national electric vehicle battery industry due to the lack of priority for solving complex multicriteria problems so that the downstream program of several mineral commodities such as nickel, copper, and bauxite which are prohibited for export is deemed not optimally carried out for sustainable development in the electric vehicle battery industry. National. So that the choice of exporting raw mineral materials or their derivative products is considered by some parties to be still an option for domestic use, coupled with the existence of lawsuits from countries exporting mineral raw materials from Indonesia which do not support the policy of domestic refining obligations.

The purpose of the study is to provide strategic recommendations to maximize the increase in the added value of minerals in creating a sustainable electric vehicle battery industry by looking at priority problems and strategic priorities related to Indonesia's policy to increase the added value of minerals to create sustainable development. The limitation in this study is to use the AHP method as data input and output results using Expert Choice V11 analysis software, the study only covers the discussion of nickel mineral as a raw material for electric vehicle batteries, and the problem criteria are only limited to economic, social, and environmental issues.

\section{Material and Methods \\ Research methodology}

In implementing mineral downstream program policies in Indonesia, one of which is for the sustainable development of the electric vehicle battery industry, support and commitment from the Government, relevant stakeholders, and the community around mining areas will affect one of which is APBN revenues. Government policies related to energy resource management are more economical using traditional decision support tools in economic and financial fields, namely costbenefit analysis (CBA) (Batubara et al., 2016). In solving comprehensive problems to support sustainable development needs that require consideration from many aspects, decision support tools can be changed using multicriteria analysis Multi-Criteria Decision Analysis (MCDA). MCDA is a method that can be used in decision making, one of which can be used in the sustainable energy sector because it has the nature of solving multi-dimensional problems such as socio-economic and environmental problems (Pohekar \& Ramachandran, 2004). In addition, the MCDA method was also developed to assist policymakers in taking/making decisions in considering several criteria for problems that may conflict with each other such as criteria for economic, technological, social, political, and environmental problems (Velasquez \& Hester, 2013; Wang et al., 2010). Some examples of MCDA methods that have been used in general include the Analytic Hierarchy Process (AHP), Multi-Attribute Utility Theory (MAUT), Simple Multi-Attribute Rating Technique (SMART), 
Technique for Order of Preference by Similarity to Ideal Solution (TOPSIS), Elimination and Choice Expressing Reality (ELECTRE) and Preference Ranking Organization Method for Enrichment Evaluation (PROMETHEE) (Behzadian et al., 2010). MCDA has a final solution that is more directed to the ranking relationship of the various problem or alternative criteria so that decisions can be made from the best to the last option that can be done (Batubara et al., 2016).

In supporting the Government's policy related to increasing the added value of minerals to overcome the multicriteria problems and challenges faced in the development of a sustainable electric vehicle battery raw material industry, by analyzing the priority criteria for problems and the priority of complex alternative solutions to be formed into a usable hierarchy. In the decisionmaking system. The analysis can be started by defining the problem and determining the desired solution, then creating a hierarchical structure that begins with the general goals to be achieved, then determining the problem and selected alternative criteria. The AHP method was chosen because the AHP method can analyze data and input information obtained through pairwise comparison techniques on a ratio scale. At the same time, the output wants to be presented in a complete ranking with scores. In addition, AHP also has a very long history, and its validity has been tested, thus making this method has many advantages over other methods (Diputra). In addition, AHP can be used to collect qualitative and quantitative facts, which can later be synthesized into a priority scale (Zhou \& Yang, 2020). AHP is built on three principles that aim to solve complex problems and become structured in a hierarchy of criteria, the principle of hierarchical arrangement (Decomposition), the principle of prioritization (Comparative Judgment), and the principle of logical consistency (Saaty, 2008). Decision-making using AHP requires standard steps so that rational and consistent decisions can be obtained. Figure 1 shows the methodology of this study.

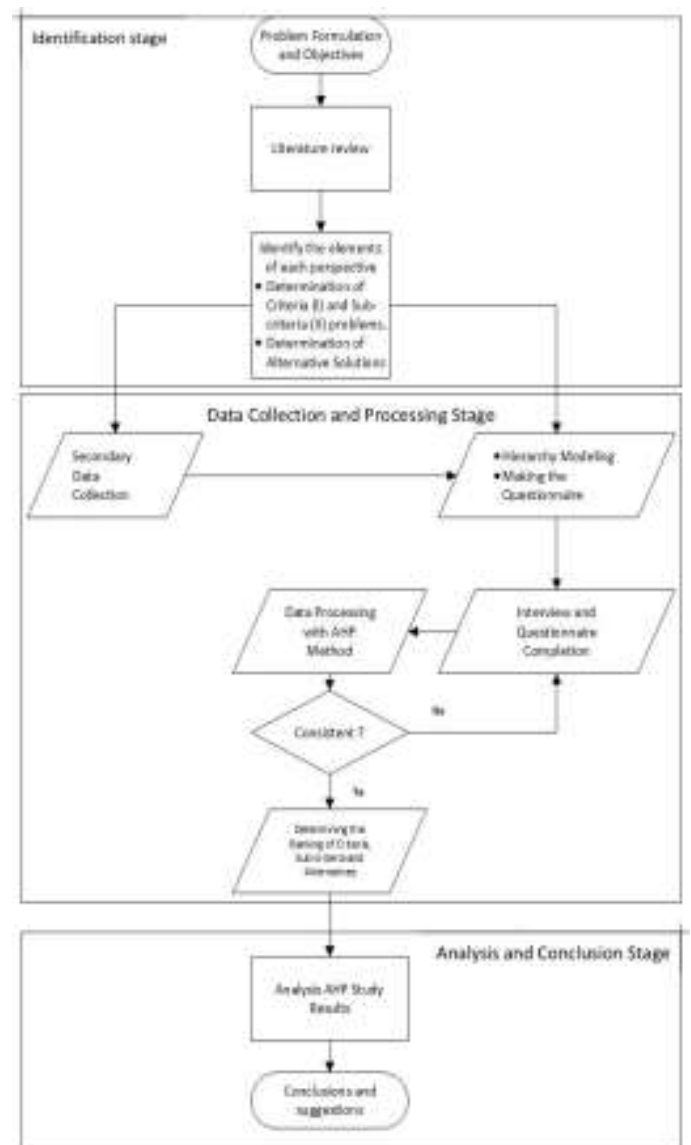

Figure. 1 An overview of the methodology of the research 
In making comparisons, it is conducted using an absolute rating scale that represents how much one element dominates another element to the attribute given in the form of a numerical value that has been set by Saaty between 1 to 9 , as in Table 1 (Saaty, 2008), as follows:

Tabel 1. AHP rating scale

\begin{tabular}{lll}
\hline $\begin{array}{l}\text { The intensity of importance on } \\
\text { an absolute scale }\end{array}$ & Definition & Explanation \\
\hline 1 & $\begin{array}{l}\text { Equal importance } \\
\text { Moderate importance of one } \\
\text { over another } \\
\text { Essential or strong importance } \\
\text { Very strong importance }\end{array}$ \\
5 & $\begin{array}{l}\text { Extreme importance } \\
\text { Intermediate values between the } \\
\text { two adjacent judgments } \\
\text { If activity } i \text { has one of the above numbers assigned to it when com- } \\
\text { pared with activity } f \text {, then } f \text { has the reciprocal value when compared } \\
\text { with } i\end{array}$ \\
Rations arising from the scale & $\begin{array}{l}\text { If consistency were to be forced } \\
\text { by obtaining } n \text { numerical values } \\
\text { to span the matrix }\end{array}$ \\
Reciprocals & & \\
Rationals & & \\
& &
\end{tabular}

The absolute numbers are arranged as a rating scale based on the human ability to evaluate qualitatively and quantitatively. Both qualitative and quantitative criteria can be compared according to the predetermined judgment to produce weights and priorities. The weights or priorities are calculated by manipulating the matrix or by solving mathematical equations.

One of the main assumptions of the AHP model that distinguishes it from other decisionmaking models is that there is no absolute consistency requirement. With the AHP model that uses human perception as its input, inconsistency is very likely to occur because humans have limitations in expressing their perceptions consistently, especially if they must compare many criteria. Based on this condition, humans can express their perceptions freely without thinking about whether their perceptions will be consistent or not. The most accurate method for comparison matrices is used in calculating priority weights, namely by mathematical operations based on matrix and vector operations known as Eigenvectors (Kusumawanto, 2014). In addition, the calculation of the maximum eigenvalues and eigenvectors from the Judgment Matrix allows a specific error range (Zhou \& Yang, 2020). The relationship between weight vector, $\lambda$ max, matrix $\mathrm{A}$ and the formula of the consistency index (CI) is as follows:

A. $\omega=\lambda \max . \omega$

Where:

$\omega:$ weight vector, weight vector needs to be normalized to achieve the matrix for a priority order. $\lambda$ max: eigenvalue

A: square matrix

$C \mathrm{I}=\frac{\lambda \max -\mathrm{n}}{\mathrm{n}-1}$

Where:

$\mathrm{n}=$ the number of the evaluated factors in the Judgement Matrix

$\mathrm{CI}=$ consistency index

Calculating the consistency ratio (CR) with the formula: 
$C R=\frac{C I}{R I}$

Where RI is a Random index which is the number of $n$ (number of criteria) whose value can be determined based on Table 3, as follows:

Tabel 2. Random consistency

\begin{tabular}{llllll}
\hline Matrix Size & 1 & 2 & 3 & 4 & 5 \\
Random Index & 0 & 0 & 0,58 & 0,9 & 1,12 \\
Matrix Size & 6 & 7 & 8 & 9 & 10 \\
Random Index & 1,24 & 1,32 & 1,41 & 1,45 & 1,49 \\
\hline
\end{tabular}

(Saaty, 1990a)

Measurement of the consistency of respondents in filling out the questionnaire is intended to see the inconsistency of the responses given by the respondents. The Consistency Ratio (CR) value allowed is CR 0.1 (Saaty, 1990b); if it is greater than $10 \%$ of the CR value, then the data collection (preference) needs to be repeated. The weakness of this method is that it is difficult to do it manually, mainly if the matrix consists of three or more criteria so that it requires the help of a computer program to solve it.

\section{Questionnaire data collection}

The sampling technique is something that needs to be considered in the selection of respondents. In this study, the selection of respondents was carried out by purposive sampling, which is included in the non-probability sampling technique. Purposive sampling is a sampling technique with special considerations. It is worthy of being a sample or deliberate selection considering that the respondent is an actor or actor (Taqwa, 2018). The input data in this study were obtained from interviews using questionnaires to experts or experts who know deep in the sector of increasing mineral value added in Indonesia. Sixteen respondents were involved in this study, where the respondents in this study consisted of the Government, Private / State-Owned Enterprises, Reviewers of Technology Applications, and Academics. The purpose of interviewing the experts is to determine the priority of the criteria that have been determined by filling in the pairwise matrix using the AHP method. In filling out problems and alternatives in the pairwise matrix, the researcher first conducted a literature study and discussed the parameters that influenced it with the experts. The experts got clear information about the main objectives and results to be achieved in this study.

Data collection is done by distributing questionnaires to interact well and produce answers following the main objectives that have been set. In this study, 11 questions represented the criteria for problems and the selection of alternative criteria. The difference between interviews with questions questionnaires is that interviews allow for interaction between questions and their meaning. In interviews, the analyst can filter a question, define terms that are not clear, change the flow of questions, respond to complex views, and generally control so that according to the context. Some of the opportunities above are also possible in the questionnaire (Taqwa, 2018).

\section{Risk management in the sustainable development of the value-added mineral policy for the raw materials industry of electric vehicle battery}

Sustainable development is an attempt to meet the needs of the present without interfering with the fulfillment of future needs and without interfering with the ability of future generations to meet their needs. The concept of Sustainable Development consists of three interrelated aspects, namely economic development (profit), environmental sustainability (planet), and social inclusion (people) (Arif, 2018). So, if there is a problem in one aspect that cannot be solved, it will impact other aspects. Figure 2 describes the relationship between economic and social, which is 
expected to create a fair (equitable) relationship. Furthermore, the relationship between the economy and the environment is expected to continue (viable). In comparison, the relationship between social and environmental aims to be sustainable (bearable).

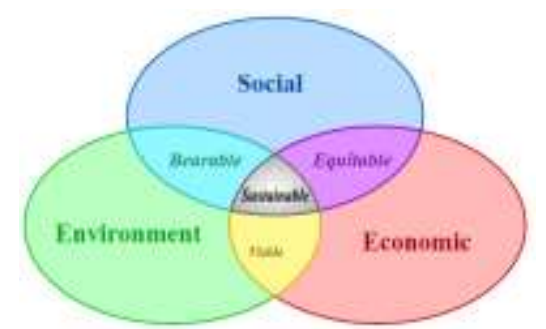

Figure 2. General scheme of sustainable development (B. Equitable)

Sustainable mining is a mining activity that is integrated with the processing industry. There are three dimensions of sustainability so that mining conditions are healthy and legal, people are prosperous, and the environment is protected (Zulkarnain, 2008). In line with the concept of the Energy Reserve Strategy, the mineral resources owned by Indonesia should be able to provide optimal benefits for sustainable development if appropriately managed to ensure environmental sustainability, social and political interests, and economic justice for present and future generations (Barma et al., 2012). This definition is also applied in carrying out "Sustainable" Mining as stated in Law Number 4 of 2009 Article 2, which is defined as the principle that in a planned manner integrates the economic, environmental, and sociocultural dimensions in the overall mineral and coal mining to realize present and future prosperity. In the mining sector, the problem is environmental degradation, which is always defeated by the economy (Dansereau, 2005). This problem occurs due to the imbalance of the three aspects of sustainability. The source of the problem and the solution are allegedly closely related to aspects of the Government's public policy (Prabawa, 2020).

Technical aspects and economic activities can influence economic criteria in the concept of sustainability in the mining sector. Economic growth in the mining sector also means achieving long-term sustainability in planned production volumes and meeting customer needs, achieving economic efficiencies derived from the sale of excavated minerals (Dubinski, 2013), and mineral resources are very essensial for many people industry by providing raw materials for other industries. Second, per-mining income can meet state revenues and enable developing countries to generate new economic opportunities. Third, the mining sector can encourage other related activities, including office supplies and equipment, spare parts, machinery, maintenance services (Zmami et al., 2021).

Social criteria in the concept of sustainability in the mining sector can be carried out with concern for employees at work and community development in the mining environment and corporate social responsibility (CSR) programs (Dubinski, 2013; Zmami et al., 2021). Mining is a large industry that deals with many stakeholders. The existence of the mining industry in the region is very influential on the social life of the social community in the local area. In Indonesia, in carrying out community development and empowerment, mining companies do not take over the Government's responsibility in CSR but rather strengthen the development policy strategies that have been set by the Government (Direktor Jenderal Mineral dan Batubara Kementerian Energi dan Sumber Daya Mineral, 2017).

In addition to economic and social impacts, mining activities are closely related to environmental impacts, and usually, mining activities bring a negative image to the environment around the mine. The impact that can occur due to the opening of a mining activity area is that it can change the initial environment of an area such as land use, morphology, surface water, groundwater, aquatic and terrestrial biology, and social, cultural and economic (Joshi et al., 2006). 
The environmental impact and climate change by mining activities are hotly discussed issues globally, besides the impact on flora and fauna around the mining area. Therefore, the mining sector should strive to minimize the environmental impact of all mining activities by implementing good mining practices that pay attention to environmental issues.

\section{Alternative strategy nickel management in Indonesia}

The mining and nickel mineral processing industry has high risks but also great benefits. If managed properly, the policy of increasing the added value of minerals, one of which is nickel, can have a positive impact as capital for the sustainable development of a region or country. The nickel mining industry and its processing industry have significant benefits, which can support the development of a sustainable electric motor vehicle battery raw material industry. The cost of producing electric motors will be cheaper and not dependent on other countries. Batteries are the most vital component for electric vehicles and contribute $35 \%$ to $40 \%$ of the total price of electric motorcycles. The highest cost in making batteries is the material cost, which reaches $60 \%$ of the total cost. Nickel mining and its processing industry can increase state revenues for equitable development, especially for other regions that do not have mineral wealth and can pave the way for economic activity or other industries. This industry cannot stand alone if it is not supported by industry or other industries.

In general, from the various problems and challenges of sustainable development in maximizing the policy of increasing the added value of minerals for the sustainable development of the electric vehicle battery industry, it is necessary to address immediately, there are three recommendations for alternative criteria that can be used so that the nickel management industry in Indonesia can provide benefits, especially for the supply chain of supporting industries and communities around the industry, namely:

- Improvement of Mining Governance and National Intermediate and Downstream Mineral Industry.

- Infrastructure and Technology Development.

- Improvement of Information System Data Availability and Quality

\section{Results and Discussion}

In implementing the policy of increasing the added value of nickel minerals that has been carried out since 2009, it is necessary to analyze and evaluate the problems that can hinder the benefits of this industrial activity. Implementing systematic risk management is expected to identify potential priority problems that have existed so far with knowing the priority of alternative solutions to solve these problems. It is hoped that the nickel management industry from upstream to downstream can impact other renewable and sustainable sector developments by carrying out good and correct planning and implementation. This study identified several problems and challenges faced in maximizing the increase in the added value of minerals in Indonesia to benefit the development of a sustainable electric vehicle battery industry influenced by three main criteria: economic, social, and environmental. The sub-criteria of the main risk criteria describes the reasons for the risk being placed on the second and third levels. Figure 3 shows an overview of the AHP model for risk management to maximize mineral value-added policies to develop a sustainable electric vehicle battery industry. 


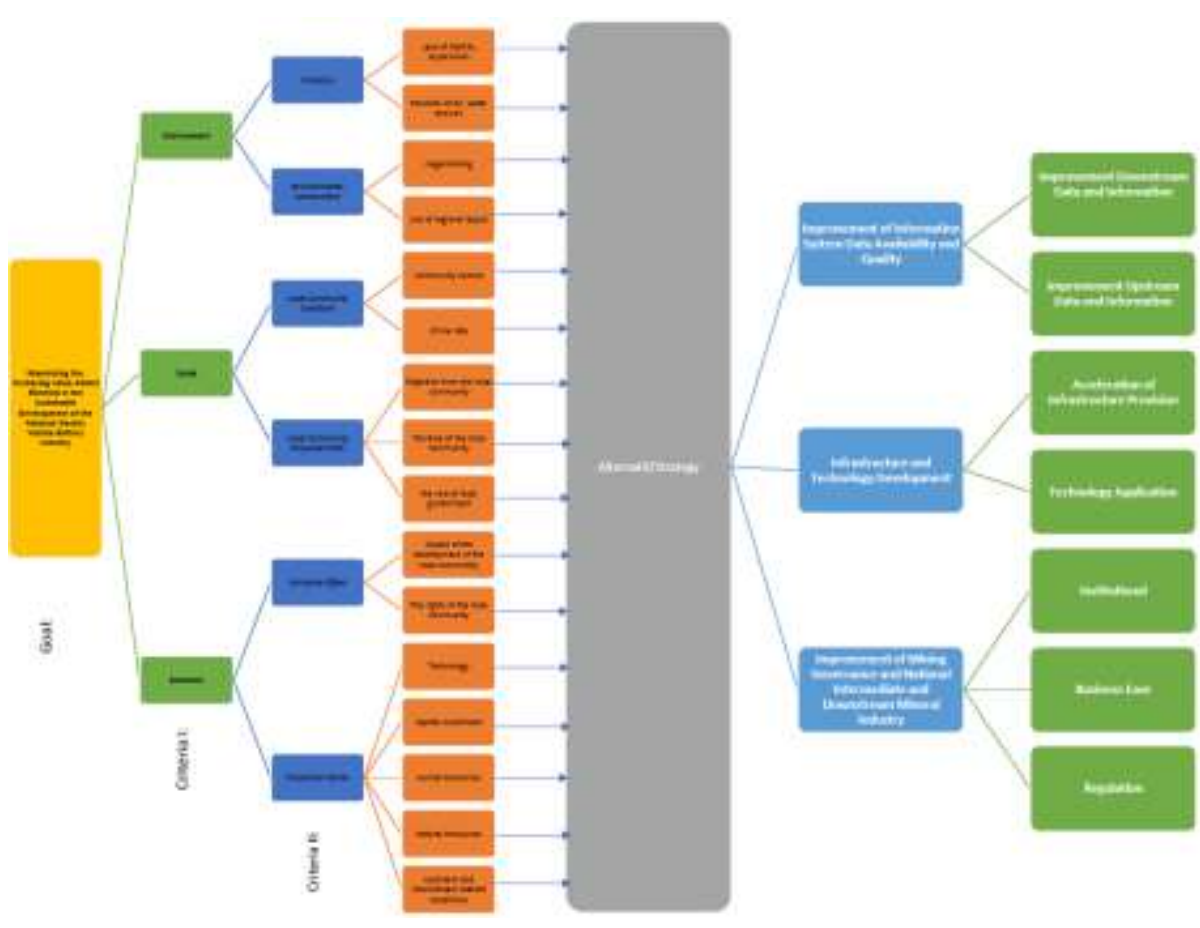

Figure 3. AHP model for risk assessment

In the economic criteria, two main factors influence the factors of production and the multiplier effect. The factors of production are influenced by Human Resources, Natural Resources, Investment, Technology, and Upstream and Downstream Market Conditions. At the same time, the problematic factors that can affect the multiplier effect are the minimal rights obtained by the local community and the minimal impact of regional development on the local community. In addition to the problems contained in the economic criteria, various problems and challenges faced in the policy to increase the added value of minerals are social criteria. Factors that influence the social criteria are the empowerment of the local community and the condition of the local community. The empowerment of the local community is influenced by the minimal role of the local community in the mining and smelter areas, the minimal role of the Local Government in empowering the local community, and rejection from the local community. The problem of the condition of the local community is influenced by the problem of crime rates and problems of community culture. Other problems and challenges faced in the policy to increase the added value of minerals, besides being contained in economic and social criteria, are also contained in environmental criteria. Environmental criteria are influenced by environmental conservation and pollution factors. The issue of forest land clearing influences environmental conservation, the use of overlapping spatial plans, the existence of illegal mining, while the pollution problem is influenced by air, water, and soil pollution in the mining and smelter areas and the lack of AMDAL supervision of the mining area and smelter industry.

In general, the various problems and challenges of sustainable development in maximizing the policy of increasing the added value of minerals for the sustainable development of the electric vehicle battery industry need to be addressed immediately. This industry can provide benefits, especially for the supply chain of supporting industries and communities around the industry, namely by improving Mining Governance and National Intermediate and Downstream Mineral Industry. It can be interpreted as improving nickel mining management policies, which are considered less supportive of new investors and existing investments. What is meant by governance here is an effort to make changes and renewals. Fundamental to the system of governance related to aspects of institutional (organization), management (business process), and 
human resources of the apparatus, one of the main weaknesses in policy is the implementation or execution in the field, so changes are needed in the bureaucratic system.

Furthermore, Infrastructure Development and Technology Development, which is building the nickel processing industry for the raw material for electric vehicle batteries, build the required smelters and requires long-term technology and infrastructure that supports these facilities to operate and encourage regional economic growth. In addition to improving governance, infrastructure development, and technology, it is also necessary to improve the availability and quality of information system data. The availability and quality of information system data are related to data that has met various requirements, geologically, mining technology, processing, refining, and economic, environmental, social, political, and legal issues issued by the Agency or Institution appointed by the Government. Improvement and data integration from upstream to downstream is needed to attract new investment in developing Indonesia's electric vehicle battery raw material industry.

The weighted analysis of the level I criteria is related to the main issues, namely Economic, Social and Environmental. The results of the calculations in the priority vector-matrix level I criteria using the help of Software Expert Choice, which show that at this level I criteria, the economic criteria are the determining criteria that must be considered with a weight of $46 \%$. So that the ranking is rank 1 , followed by social criteria with a weight of $27 \%$ ranked 2 , and environmental criteria with a weight of $26 \%$ ranked 3 . An inconsistency value (CR) obtained of $0.00019 \%$ indicates that filling out the questionnaire carried out the existing choices are consistent (maximum limit of inconsistency is $0.1 \%$ ).

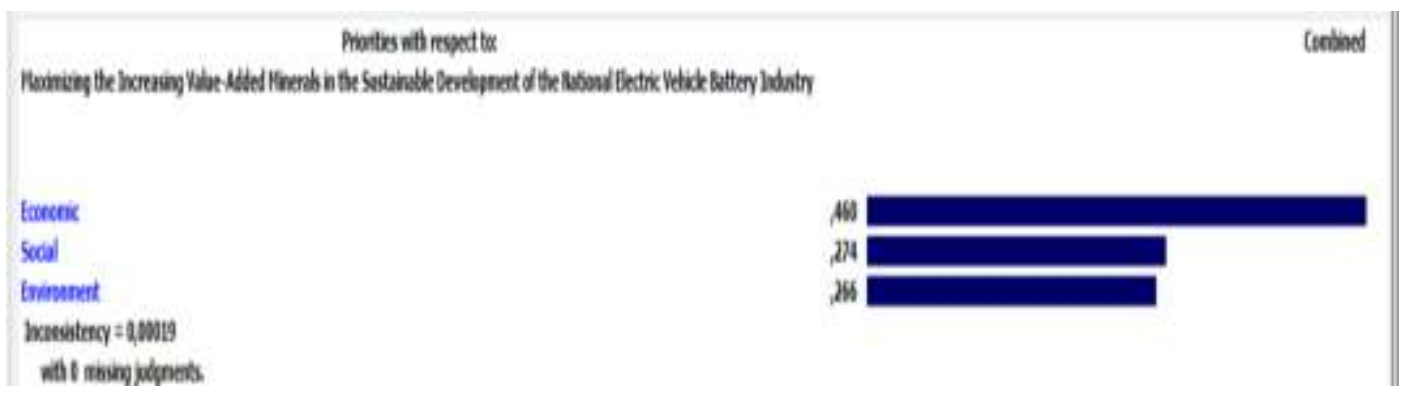

Figure 4. Criteria I pairwise matrix calculation using Expert Choice Software

The calculation simulation results for ranking each priority show that the main problem criteria are economic problems influenced by production factors and multiplier effects as level 2 criteria. $72 \%$ weight, while the influencing factor in the multiplier effect weights $23 \%$. Figure 5 shows ranking level II Criteria for each main issue in level I Criteria.

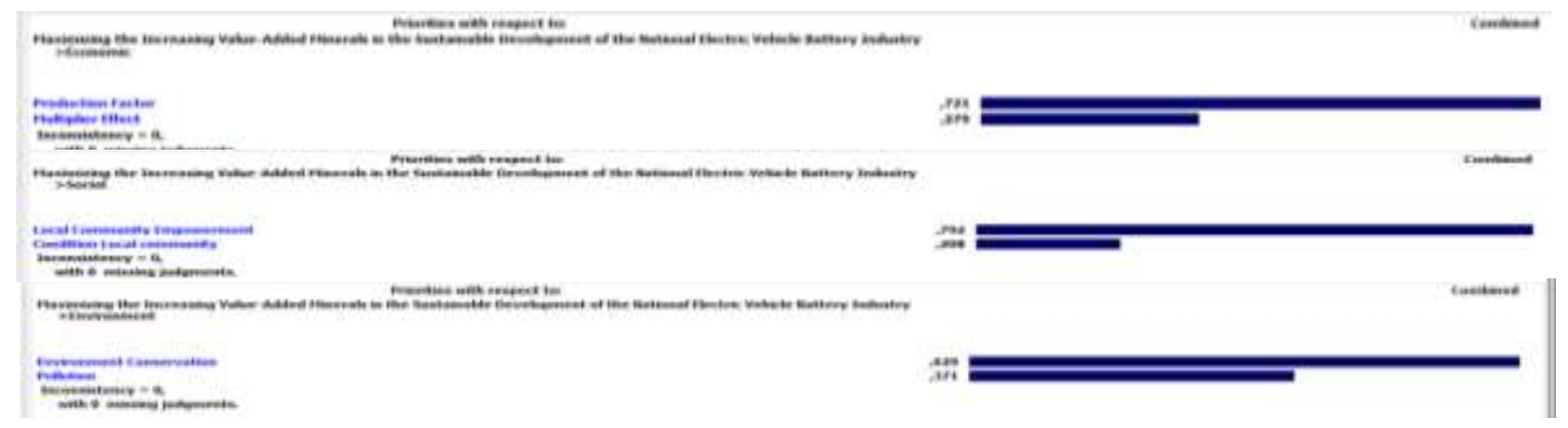

Figure 5. Level II criteria pairwise matrix 
Sensitivity analysis was carried out to see changes in the weight values in the level I and II criteria into the final weighting. The priority of alternative solutions to overcome the problems faced is to maximize the increased mineral value added to create a sustainable development of the electric vehicle battery industry. An example is increasing the weight of the economic, Social, and Environmental criteria on the priority of alternative solutions to overcome the problems faced. The simulation results for the analysis of the selection of alternative strategies show that the first ranking alternative is the Improvement of Mining Governance and the National Intermediate and Downstream Industries with a weight of 51\%, followed by the alternative of Infrastructure Development and Technology Development with a weight of 31\% which ranks 2 . The alternative of improving the Availability and Quality of Data Information systems with $18 \%$ is ranked 3 . With an inconsistency value (CR) obtained of $0.02 \%$.

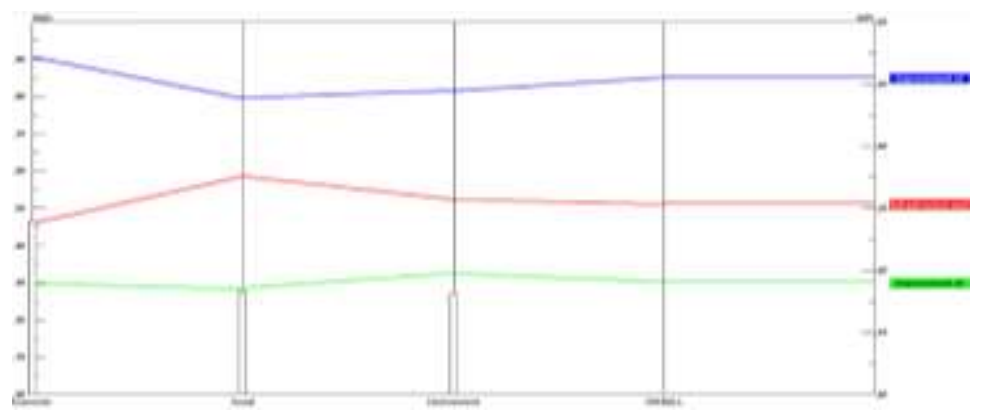

Figure 6. The sensitivity of alternative solutions to the problem

Conclusion

1. In maximizing the role of increasing the added value of minerals in Indonesia in supporting the sustainable development of the electric motor vehicle raw material industry, it is influenced by several criteria for the problem factors,

- In problem criteria level I, the consideration of Economic factors is considered to have a greater weight and is more important than Social or Environmental factors.

- The weight of the sub-criteria assessment for level II problems from the Economic Criteria is a Production Factor rather than a multiplier effect criteria factor.

2. Improvement of Mining Governance and the National Intermediate and Downstream Industry needs top priority in solving economic problems such as production problems. Harmonization Policy from upstream to downstream between Ministries/Institutions, increasing ease of business, such as providing certainty, facilitation of upstream to downstream industrial supply chains, and providing incentives by the Government for mining companies that carry out downstream are some of the ways to fix problems in production factors. For the multiplier effect problem, it is influenced by rights obtained by the community around the development, often corporate social responsibility programs such as the Corporate Social Responsibility (CSR) program carried out by the company are only temporary programs such as direct giving in the form of money to the community and have not been implemented. Touch on sustainable community development programs. In carrying out CSR programs, programs are needed based on the needs of the local community, such as the construction of education and health facilities, providing capital loans for Small and Medium Enterprises (SMEs), providing scholarships, strengthening local wisdom, and others by developing community-based social protection schemes and so on.

3. The lack of contribution from the increase in added value in the development of the local area is still common. Development in the mining area and the smelter industry causes uneven development and social inequality with people in other areas. Therefore, the current institutional improvement factors, such as the Eradication of Corruption (Good Governance), Strengthening Public Participation, Strengthening BUMN and BUMD, and Development of 
community-based social protection schemes need to be carried out as a top priority followed by alternative strategies for Infrastructure Development and Technology Development as well as improvements availability and quality of information data systems to maximize the role of sustainable value-added minerals in solving economic, social and environmental problems in the electric vehicle battery raw material industry.

\section{Acknowledgment}

The author would like to thank the 16 respondents who were willing to help in this writing. I am also hugely appreciative to Mr. Yudo Dwinanda Priaadi the Expert Staff of the Minister for Strategic Planning at the Ministry of Energy and Mineral Resources, the Expert Team for the DS 592 WTO Case (Prof., Dr., Ir., Rudy Sayoga Gautama, Mr. Agus Superiadi as Director of Support and Site Services PT Vale Indonesia Tbk, and Mr. Adi Maryono as Chair of KCMI), as well as colleagues from the Directorate General of Mineral and Coal of Ministry of Energy and Mineral Resources, Special thanks also to my supervisor Prof.Ir Rinaldy Dalimi M.Sc, Ph.D. for his wholeheartedly for his tremendous academic support.

\section{References}

Arif, I. (2018). Nikel Indonesia. Gramedia Pustaka Utama.

Barma, N., Kaiser, K., \& Le, T. M. (2012). Rents to riches?: The political economy of natural resource-led development. World Bank Publications.

Behzadian, M., Kazemzadeh, R. B., Albadvi, A., \& Aghdasi, M. (2010). Promethee: A comprehensive literature review on methodologies and applications. European journal of Operational research, 200(1), 198-215.

Batubara, M., Purwanto, W. W., \& Fauzi, A. (2016). Proposing a decision-making process for the development of sustainable oil and gas resources using the petroleum fund: A case study of the East Natuna gas field. Resources Policy, 49, 372-384.

Dalimi, R. (2020). Draft menuju era energi terbarukan.

Dansereau, S. (2005). Win-win or new imperialism? Public-private partnerships in Africa mining. Review of African Political Economy, 32(103), 47-62. https://doi.org/10.1080/03056240500121024

Diputra, E. M. (2018). Analysis of the Assessment Factors for Energy Planning in Indonesia using Analytic Hierarchy Process," 서울대학교 대학원.

Dubiński, J. (2013). Sustainable development of mining mineral resources. Journal of Sustainable Mining, 12(1), 1-6.

Direktor Jenderal Mineral dan Batubara Kementerian Energi dan Sumber Daya Mineral. (2017). Sistematika Penyusunan Cetak Biru (Blue Print) Pengembangan dan Pemberdayaan Masyarakat Pada Kegiatan Usaha Pertambangan Mineral Dan Batubara.

Joshi, P., Kumar, M., Midha, N., Yanand, V., \& Wal, A. P. (2006). Assessing areas deforested by coal mining activities through satellite remote sensing images and GIS in parts of Korba, Chattisgarh. Journal of the Indian Society of Remote Sensing, 34(4), 415-421.

Kusumawanto, A. (2014). Analisis Kebijakan Pengembangan Lapangan Minyak Bumi di Indonesia Dengan Metode Analytical Hierarchy Process (AHP). Magister, Fakultas Teknik Pertambangan dan Perminyakan. ITB, Jakarta.

Pohekar, S. D., \& Ramachandran, M. (2004). Application of multicriteria decision making to sustainable energy planning-A review. Renewable and sustainable energy reviews, 8(4), 365-381.

Prabawa, F. Y. (2020). Pemodelan Sistem Dinamis Pertambangan Emas Rakyat Menuju Pertambangan Berkelanjutan Studi Penambangan Emas Rakyat Desa Kertajaya Kecamatan Simpenan Kabupaten Sukabumi Jawa Barat. Doctoral, Program Studi Ilmu Lingkungan, Universitas Indonesia, Jakarta.

Saaty, T. L. (2008). Decision making with the analytic hierarchy process. International journal of services sciences, 1(1), 83-98.

Saaty, T. L. (1990a). Decision making for leaders: the analytic hierarchy process for decisions in a complex world. RWS publications.

Saaty, T. L. 1990b). How to make a decision: the analytic hierarchy process. European journal of operational research, 48(1), 9-26.

Taqwa, M. (2018). Penerapan metode monte carlo pada penjadwalan proyek konstruksi (Studi kasus: Proyek pembangunan apartemen the Reiz Condo Medan).

Velasquez, M., \& Hester, P. T. (2013). An analysis of multicriteria decision making methods. International journal of operations research, $10(2), 56-66$.

Wang, J.-J., Jing, Y.-Y., Zhang, C.-F., \& Zhao, J.-H. (2009). Review on multicriteria decision analysis aid in sustainable energy decisionmaking. Renewable and sustainable energy reviews, 13(9, pp. 2263-2278, 2009.

Zhou, S., \& Yang, P. (2020). Risk management in distributed wind energy implementing analytic hierarchy process. Renewable Energy,150, 616-623. https://doi.org/10.1016/i.renene.2019.12.125

Zmami, M., Ben-Salha, O., Almarshad, S. O., \& Chekki, H. (2021). The contribution of mining sector to sustainable development in Saudi Arabia. Journal of Sustainable Mining, 20(2), 122-136.

Zulkarnain, I. (2008). Konsep pertambangan rakyat dalam kerangka pengelolaan sumber daya tambang yang berkelanjutan. Pusat Penelitian Geoteknologi, Lembaga Ilmu Pengetahuan Indonesia. 